\title{
Microbiological Quality of Soft White Cheese Produced Traditionally in Jordan
}

Haddad MA ${ }^{1 *}$ and Yamani MI $^{2}$

${ }^{1}$ Faculty of Agricultural Technology, Department of Nutrition and Food Technology, Al-Balqa Applied University, Salt, Jordan

${ }^{2}$ Department of Nutrition and Food Technology, School of Agriculture, The University of Jordan, Amman, Jordan

\begin{abstract}
To determine the hygiene and processing aspects and the microbiological quality of soft white cheese produced traditionally in Jordan, 30 samples were collected from dairy workshops and plants in major Governorates of Jordan. A questionnaire was filled by interviewing each producer about the quality, Food hygiene and safety aspects of production prevailing during processing were also investigated.

The averages of $\log _{10}$ of the standard plate count (SPC), and the counts of lactic acid bacteria count (LABC), Enterobacteriaceae (EntC) and yeast and mold (Y\&MC) were 8.3, 7.9, 5.4 and 3.0, respectively. A significant positive correlation (0.90) was noticed between SPC and LABC, indicating that most of SPC were LABC. Staphylococcus aureus count ranged between $5-8 \mathrm{log}_{10} \mathrm{CFU} / \mathrm{g}$ whereas Salmonella was positive in $25 \mathrm{~g}$ in three cheeses samples of Madaba and Amman governorates which certainly pose health hazard. The averages of $\mathrm{pH}$, acidity (\% lactic acid), moisture and salt $(\mathrm{NaCl} \%)$ in brine and in cheese and ash were 6.0 , $0.53 \%, 56.5 \%, 12.6 \%, 9.4 \%$, and 9.5 , respectively. Fourteen of the samples gave positive results to the alkaline phosphatase test, denoting the probability of using unpasteurized milk in the production. The high microbial content of the cheese samples especially S. aureus and presence of Salmonella in few samples reflects generally the poor hygienic conditions during production and storage, lack of refrigeration and absence of heat treatment to eliminate microorganisms. It could be concluded also from the results of the questionnaires that there is a lack of standardized method for production and keeping of soft white cheese in Jordan.
\end{abstract}

Keywords: Microbiological quality; Soft white cheese; Traditional dairy products; Food safety; Dairy microbiology; Jordan

\section{Introduction}

The major cheese type produced in Jordan is the soft white cheese (juben balady) [1]. According to the Jordanian standards for soft cheese (JS 246: 2006); soft cheese is defined as un ripened soft cheeses ready to eat directly after processing. Its acidity should not exceed $1.9 \%$ as lactic acid and should be kept under refrigeration. In Jordan soft white cheese is usually produced seasonally from ewes or goat milk, or a combination of both, without addition of a starter culture or salt under un mechanized or artisanal conditions and is handled at various stages of manufacture. The method of production could be summarized in coagulating the milk for 40-60 min by rennet (Rennet is a natural complex of enzymes produced in any mammalian stomach to digest the mother's milk, and is often used in the production of cheese) after heating to about $35^{\circ} \mathrm{C}$ then pressing in cheese cloth. The cheese is usually directly consumed after production or used in the production of some Arabian confectioneries such as kunafeh. This soft white cheese has a very limited keeping ability even under refrigeration; various types of microorganisms may enter the cheese during manufacture and subsequent handling [2-4]. A good portion of the soft white cheese produced seasonally in Jordan is used in the production of boiled white cheese [5].

A number of experimental studies have been executed on the Jordanian soft white cheese including meltability and stretch ability [6], kinetic sensorial analysis [1], use of fungal rennin-like enzyme in the manufacturing [7], in-can heating preservation of nabulsi cheese with emphasis on halotolerant bacteria' [8], halophilic bacteria of cheese, and quality of cheese [9], the isolation of salt tolerant bacteria for use in the production of nabulsi cheese [10], nabulsi a Jordanian cheese [11], the effect of $\mathrm{pH}$ and salt concentrations of the brine on the storage ability and sensory quality of boiled white cheese [5], in-bag steaming of white brined cheese as a method for preservation [2], effect of the addition of yoghurt whey to cow milk on curd formation [12], and improving the traditional method of producing boiled brined white cheese [3]. The objective of the study was to investigate the characteristics of the indigenous flora in the Jordanian soft white cheese. Such knowledge is needed to improve the technological production and to guarantee typical properties.

\section{Materials and Methods}

\section{Sampling}

Thirty cheese samples were collected from major Jordan Governorates (Amman, Al-Balqa, Jerash and Madaba) using icebox. Pre-sterilized forceps wrapped with foil was used to take samples of soft white cheese from each determined site in the Governorates, and was put in pre-sterilized sealable plastic bags at $500 \mathrm{~g}$ from each site. A questionnaire for information collection about the cheese was filled at the time of sampling by interviewing the cheese producers.

\section{Microbiological testing}

Sample homogenate was prepared using $25 \mathrm{~g}$ of each sample taken from three different pieces avoiding the surface into pre-sterilized bag, and $225 \mathrm{ml}$ of $2 \%$ sodium citrate dilution buffer at $40^{\circ} \mathrm{C}-45^{\circ} \mathrm{C}$ was added. Appropriate serial dilutions were made [13].

Standard plate count (SPC): Standard plate count was executed using plate count agar by pour plate method according to Laird et al. [13]. The dishes were incubated at $32 \pm 1^{\circ} \mathrm{C}$ for $48 \pm 3 \mathrm{~h}$. The number was calculated and expressed as $\mathrm{CFU} / \mathrm{g}$ cheese.

*Corresponding author: Haddad MA, Faculty of Agricultural Technology, Department of Nutrition and Food Technology, Al-Balqa Applied University Salt-19117, Jordan, Tel: +962-777-394229 ; Fax: 00962-5-557518; E-mail: maahaddad@yahoo.com

Received November 17, 2017; Accepted December 06, 2017; Published December 13, 2017

Citation: Haddad MA, Yamani MI (2017) Microbiological Quality of Soft White Cheese Produced Traditionally in Jordan. J Food Process Technol 8: 706. doi: 10.4172/2157-7110.1000706

Copyright: (c 2017 Haddad MA, et al. This is an open-access article distributed under the terms of the Creative Commons Attribution License, which permits unrestricted use, distribution, and reproduction in any medium, provided the original author and source are credited. 
Lactic acid bacteria count (LABC): Pour plating of sample dilutions were done by using pre-prepared sterilized MRS agar (Oxoid, UK). Plates were incubated at $37 \pm 1^{\circ} \mathrm{C}$ for $48 \pm 3 \mathrm{~h}$ in reduced aerobic conditions. Individual colonies were tested for catalase reaction, gram reaction (Gram stain kit, Delta lab, Spain), and cell morphology. Grampositive, catalase-negative cocci, or rods were tentatively considered to be lactic acid bacteria [14]

Yeast and mold count: Yeast and mold count was made according to Frank and Yousef [14]. Plate count agar (Himedia, India) was used after two $\mathrm{ml}$ of antibiotic solution were added per $100 \mathrm{ml}$ of the medium and mixed. Spread plating technique was used and the plates were incubated at $25^{\circ} \mathrm{C}$ for $5 \mathrm{~d}$.

Staphylococcus aureus count: Baird-Parker agar (BPA) (Oxoid) using streak plate method. Plates were incubated at $35 \pm 1^{\circ} \mathrm{C}$ for 45 $48 \mathrm{~h}$. Coagulase production, catalase test, anaerobic utilization of glucose and mannitol, and Gram stain were used for more assurance [15]. Positive control of confirmed Staphylococcus aureus subsp. aureus $43300^{\mathrm{Tx}}$ was purchased and used for comparison.

Enterobacteriaceae count: Enterobacteriaceae count was done as described in the International Standard, ISO 21528-2: 2004. Pour plate technique was applied using violet red bile glucose agar (VRBG) (Oxoid). Plates were incubated at $37^{\circ} \mathrm{C}$ for $24 \mathrm{~h} \pm 2 \mathrm{~h}$. Enterobacteriaceae suspected colonies were confirmed by Gram stain, Oxidase test, and oxidation/fermentation test.

Presence of Salmonella: Sample homogenate was prepared using lactose broth and incubated at $35^{\circ} \mathrm{C}$ for $24 \pm 2 \mathrm{~h}$ (Pre enrichment step).

Isolation of Salmonella: Amount of $10 \mathrm{ml}$ mixture was transferred to $100 \mathrm{ml}$ selenite cysteine broth (CS) (Himedia). The mixture was vortexed and incubated for $18-24 \mathrm{~h}$ at $37^{\circ} \mathrm{C}$ (enrichment step). Incubated cultures were mixed and streaked on brilliant green agar (BG) (Himedia, India). Plates were incubated at $37^{\circ} \mathrm{C}$ for $20-24 \mathrm{~h}$, and then examined for the presence of suspected colonies Salmonella. Biochemical confirmation tests including slants of TSI (triple sugar iron agar, Himedia), LIA (lysine iron agar, Himedia), and urea agar UA, Himedia) were inoculated by streaking slant and stabbing butt. The three slants were incubated at $37^{\circ} \mathrm{C}$ for $24 \mathrm{~h}$ (ISO 6785: 2001). Positive control of confirmed Salmonella enterica subsp. enterica serovar Typhimurium $14028^{\text {tw }}$ was purchased and used for comparison.

\section{Physical and chemical tests}

$\mathrm{pH}$ of cheese titratable acidity (Lactic acid\%), Salt $(\mathrm{NaCl})$ in brine and cheese, and ash determination were executed according to Hooi et al. [16]. Moisture content was implemented as Case et al. [17]. Phosphatase test kit for milk and milk products (HEYL, Germany) was used as described by HEYL Company. Cheese sample of $0.25 \mathrm{~g}$ was added to the test reagents instead of milk. Positive and negative controls of phosphatase test were performed by manufacturing fresh soft white cheese as described by Humeid and Tukan [3], except that they were processed from raw milk without pasteurization. Cheese was then divided into two portions, the first one was boiled, which served as negative control, and the other was un-boiled, which served as positive control.

\section{Statistical analysis}

Statistical analysis for microbiological levels, physical and chemical tests were analyzed using F-test, t-test (LSD), Tukey's Studentized Range and correlation of statistical analysis software (SAS) version $9[18,19]$.

\section{Results}

\section{Hygiene and processing conditions}

This study included collecting information on processing and hygiene conditions of $20 \mathrm{soft}$ white cheese producers from the major Jordanian Governorates (Al-Balqa, Madaba, Amman, and Jerash). Conditions varied from small scale and poor facilities to medium and large relatively well-equipped facilities. Knowledge of cheese processing varied greatly. The average daily milk used in processing of soft white cheese ranged between 100-500 Kg/day (for small-scale producers) to $>500-5000 \mathrm{Kg}$ (for large-scale producers); seven of the producers could be considered according to the local norm as large-scale producers. Half of the 20 soft white cheese producers stop processing when the seasonal sheep lactation period ends; those belonged to the smallscale producers. Most of soft white cheese producers used cow' milk, others used a mix of goat and cow or goat and sheep milk. Amount of milk needed to produce one $\mathrm{Kg}$ of soft white cheese (the conversion ratio of milk to soft white cheese) varied according to the type of milk used; it ranged between 5.5-9, 6-8, 6-8, 3-6, and 2.8-4 Kg for cow milk, goat milk, cow/goat milk mix, sheep/goat milk mix, and sheep milk, respectively. It was observed that only two of the 20 cheese producers used cooling tanks for milk during transportation from the farm. Seven of the producers, mostly from large-scale producers, used a milk pasteurizer during cheese production. The rest used either stainless steel cookware (11 producers) or aluminum cookware (5 producers) or both equipment for milk pasteurization. The coagulation of milk was performed either in plastic pails (10 producers out of 20) or in stainless steel tank ( 9 producers out of 20). One of the producers used the same aluminum cookware for pasteurization, and for coagulation. Fifteen producers used stainless steel moulds for pressing the cheese, the rest of the producers used aluminum coated wood mould ( 2 producers), aluminum mould (one producer), woody mould (one producer), porcelain mould (one producer). Temperature of rennet addition ranged between $30^{\circ} \mathrm{C}$ to $38^{\circ} \mathrm{C}$. This range could affect the conversion ratio of milk to cheese. Chris-Hansen rennet was the most rennet used. Most of the producers dissolved the rennet in water either lukewarm or at room temperature before addition, except one producer who added the rennet into the milk as such. The time for complete curd formation was between $20 \mathrm{~min}$ and $150 \mathrm{~min}$, which reflects the difference in processing conditions, the specifications of required cheese, incubation temperature difference, and ambient temperature. Traditionally, some of the producers added black cumin seeds on the surface of curd. Other producers admitted that they add preservatives (e.g. natamycin). Salt addition ranged mostly between $16 \%-18 \% \mathrm{w} / \mathrm{w}$, and few used between $10 \%-14 \%$. Some small-scale processors add $\mathrm{CaCl}_{2}$ more than required for the processing of soft white cheese (up to $60 \mathrm{~g} / 100 \mathrm{~L}$ milk instead of $20 \mathrm{~g} / 100 \mathrm{~L}$ milk.) Pasteurization conditions also varied between the reasonable scientific temperature time $\left(73^{\circ} \mathrm{C} / 15 \mathrm{~s}\right)$ to extra unneeded temperatures $\left(100^{\circ} \mathrm{C} / 10 \mathrm{~min}\right)$. It was noticed that half of the processors workers did not wear special processing clothing during processing and the majority did not wear the head cap. There were multiple methods used for cleaning Cheesecloth was cleaned using boiling water, soda and commercial detergents, or chlorine with hot water or steam. Most of the producers reused the cheesecloth for about 30 times, until complete tear.

\section{Microbiological survey}

Results of the microbiological survey of the 30 soft white cheese samples collected from different Governorates are shown in Table 1. There was no significant difference $(p>0.05)$ in SPC among the 30 
cheese samples, and among different Governorates except between Amman and Al-Balqa. No significant difference $(p>0.05)$ was found in LABC among the 30 cheese samples and among different Governorates. There was no significant difference observed ( $\mathrm{p}>0.05)$ in EntC among the 30 cheese samples and among different Governorates. The highest and the lowest SPC, LABC, and Y\&MC samples were seen in Amman Governorate. The highest EntC samples were seen in Amman Governorate also, but the lowest were seen in Jerash. A significant positive correlation (0.90) was noticed between SPC and LABC, which means that most of SPC were LABC. There was also a significant positive correlation between SPC and each of EntC and Y\&MC $(0.60$, 0.39 respectively). A significant positive correlation between $\mathrm{LABC}$ and EntC (0.60) and Y\&MC (0.36).

The circular and oval colonies surrounded by zones that are gave grape-like clusters under microscope were considered as positive in cheese after confirmed on biochemical tests of $S$. aureus indicated in methodology. The confirmed tests included (coagulase, Gram stain, catalase, and anaerobic utilization of glucose and mannitol). Counts of $S$. aureus (circular and oval colonies surrounded by zones that gave grape-like clusters under microscope) ranged between $10^{5}$ and $10^{8}$ $\mathrm{cfu} / \mathrm{g}$. Eight samples were coagulase positive. Counts in these samples, which originated from Al-Balqa, all samples of Madaba, and one sample from Amman governorate were greater than $10^{7} \mathrm{cfu} / \mathrm{g}$. Samples that

\begin{tabular}{|c|c|c|c|c|c|c|}
\hline & \multicolumn{5}{|c|}{ Governorate (Samples) } & \multirow{2}{*}{ Ricrobial group } \\
\cline { 2 - 6 } & $\begin{array}{c}\text { Amman } \\
\text { (9) }\end{array}$ & $\begin{array}{c}\text { Al-Balqa } \\
\mathbf{( 1 3 )}\end{array}$ & $\begin{array}{c}\text { Jerash } \\
\mathbf{( 5 )}\end{array}$ & $\begin{array}{c}\text { Madaba } \\
\mathbf{( 3 )}\end{array}$ & Range & Average \\
\hline $\begin{array}{c}\text { Standard plate count } \\
\text { (SPC) }\end{array}$ & 8.1 & 8.8 & 8.1 & 8.3 & $6.5-10.0$ & 8.3 \\
\hline $\begin{array}{c}\text { Lactic acid bacteria } \\
\text { count (LABC) }\end{array}$ & 7.7 & 8.2 & 7.7 & 8.2 & $6.1-9.7$ & 7.9 \\
\hline $\begin{array}{c}\text { Enterobacteriaceae } \\
\text { count (EntC) }\end{array}$ & 5.5 & 5.7 & 4.3 & 6.4 & $<1.0-8.3$ & 5.5 \\
\hline $\begin{array}{c}\text { Yeast and mold } \\
\text { count (Y\&MC) }\end{array}$ & 2.3 & 3.3 & 3.9 & 4.0 & $<1.0-6.3$ & 3.0 \\
\hline
\end{tabular}

Table 1: Summary of the enumeration of different microbial groups in the 30 soft white cheese samples collected from different Governorates in Jordan. gives coagulase positive for $\mathrm{S}$. aureus are only two samples of 30 cheese samples gave positive results (per $25 \mathrm{~g}$ cheese) on three confirmed biochemical tests of Salmonella. The two samples were from Madaba and Amman (Sweileh area) governorates.

\section{Physical and chemical survey}

Figure 1 shows the $\mathrm{pH}$, salt $(\mathrm{NaCl} \%$ in cheese and brine), moisture, and ash of the soft white cheese samples collected from four Governorates in Jordan. The $\mathrm{pH}$ ranged between 6.5 and 4.9 with an average of 6.0 (Figure 1). The highest and the lowest $\mathrm{pH}$ were observed in Amman Governorate. There was no significant difference $(\mathrm{p}>0.05)$ in $\mathrm{pH}$ between the 30 cheese samples and between different Governorates. Acidity (lactic acid\%) ranged between $1.47 \%$ and $0.24 \%$ with an average of $0.53 \%$. The highest acidity was seen in Al-Balqa Governorate, whereas the lowest in Amman. There was a significant difference in acidity $(p<0.05)$ between the 30 cheese samples, but no significant difference between different Governorates, except between Amman and Al-Balqa from one hand and between Al-Balqa and Jerash from the other hand.

Moisture percentage ranged between 74.5 and 39.5 with an average of 56.5. The highest was in Amman Governorate, whereas the lowest was in Al-Balqa. There was a significant difference in moisture content $(\mathrm{p}<0.0001)$ among the 30 cheese samples, and there was a significant difference between Amman and each of Al-Balqa and Madaba from one hand and between Al-Balqa and Jerash from the other hand. Salt $(\mathrm{NaCl} \%)$ in brine and cheese ranged between 25.16 and 1.46 with an average of 12.63 for brine and 19.44 and 1.82 with an average of 9.37 for cheese. The highest and the lowest salt $(\mathrm{NaCl} \%)$ in brine and cheese, were seen in samples of Madaba and Amman Governorates, respectively. There was a significant difference in salt concentration of brine and cheese $(\mathrm{p}<0.0001)$ among the 30 cheese samples, and there was a significant difference among all Governorates except between $\mathrm{Al}$ Balqa and Madaba for salt in brine and cheese and between Amman and Jerash for salt in cheese.

Ash percentage ranged between 3.3 and 17.3 with an average of 9.5. There were significant differences in ash $\%(p<0.0001)$ among

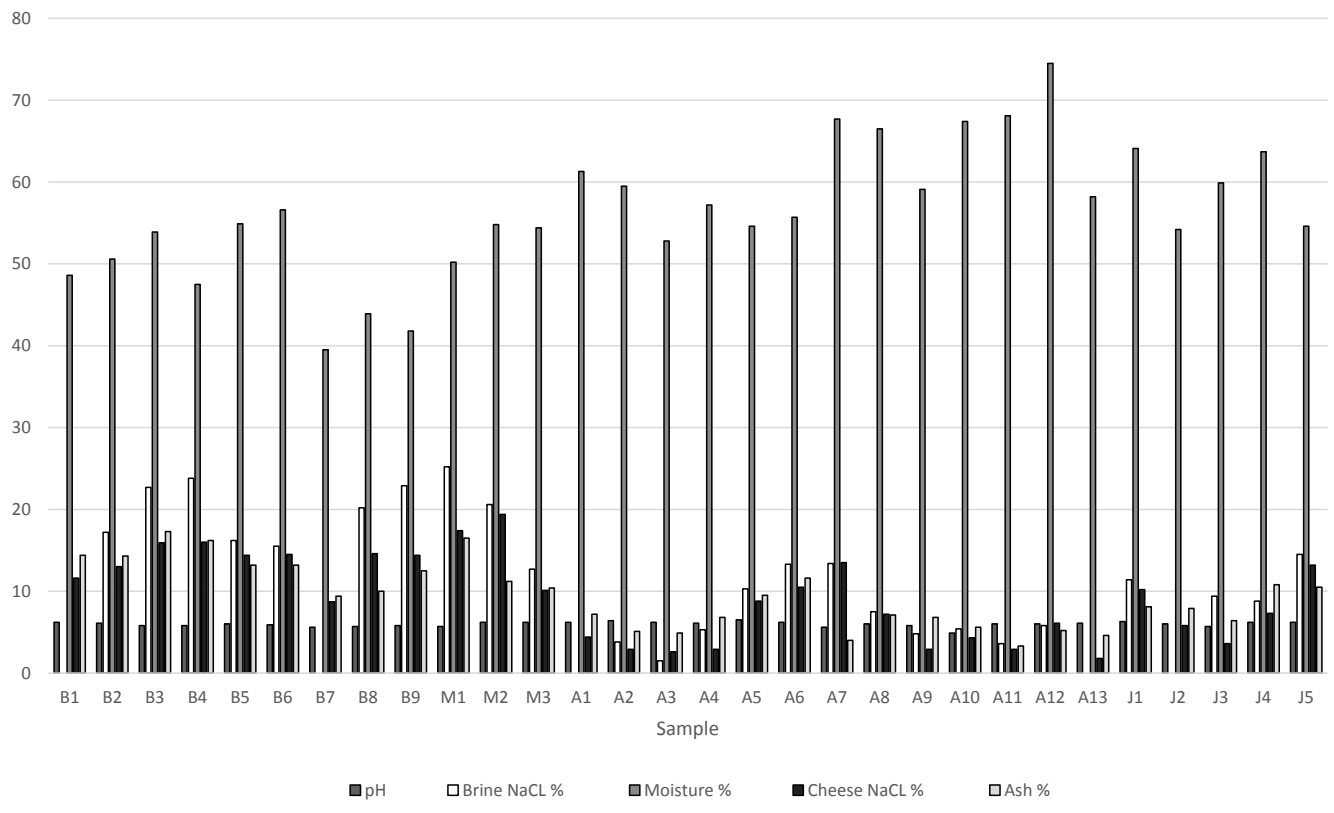

Figure 1: $\mathrm{pH}, \mathrm{NaCl}$ cheese, moisture, $\mathrm{NaCl}$ brine, ash) for thirty pasteurized soft white cheese samples collected from four different governorates in Jordan. 
the 30 cheese samples, and there were significant differences among all Governorates except between Al-Balqa and Madaba on one hand and between Amman and Jerash from the other hand. Fourteen cheese samples $(46.6 \%)$ showed a positive phosphatase test. All cheese samples of Al-Balqa and Madaba Governorates gave positive result in phosphatase test, whereas, all samples collected from Jerash gave negative result in phosphatase. In Amman 4 out of 13 (30.8\%) of the samples gave positive phosphatase test. A significant negative correlation between $\mathrm{pH}$ of the cheese and SPC and LABC $(-0.40,-0.43$, respectively) and a significant positive correlation between acidity of cheese and each of SPC and LAB ( $-0.38,-0.38$ respectively) were noticed.

\section{Discussion}

\section{Microbiological quality and safety of soft white cheese}

Soft white cheese is popular in many countries, including Jordan. Many research works have been carried out on chemical, microbiological, production and sensory aspects of this cheese in Jordan [1-3,5-12]. Soft white cheese is also popular in neighboring countries, where a good number of studies had been carried out on quality and production aspects, [20-26]. However, studies on the microbiological quality of this type of cheese in Jordan are scarce. The lack of standardized method for production and keeping of soft white cheese in Jordan, as can be concluded from the questionnaire, has resulted in the significant variations noticed in the different quality characteristics of the cheese samples. The high microbial content of the cheese samples, as seen in the SPC and LABC, reflects the general hygiene conditions used during production and storage, lack of refrigeration, and absence of steps, such as heat treatment to eliminate microorganisms in most of the tested samples. It could be postulated that the bacterial growth has mostly taken place in the milk and during the steps of production before placing the cheese pieces in brine. Fortunately, the predominant microorganisms were LABC which forms the major part of the microbial flora of fresh dairy products and which have no negative effect on the safety of the products.

Enterobacteriaceae counts were generally high and were in most samples unacceptable. Presence of Enterobacteriaceae in food samples generally indicates direct or indirect fecal contamination of the milk or the product during processing, and thus the possibility of having pathogenic bacteria, viruses, or protozoa of fecal origin in the food. The relatively low counts of yeasts have no effect on the quality or the safety of the cheese. Growth of yeasts in this type of cheese is not encouraged by the presence of LAB and having in this cheese intrinsic conditions, which encourage bacterial rather than fungal growth. Consumption of soft white cheese has been associated with food borne illnesses in Jordan and neighboring countries. Some of these illnesses are very serious, such as Malta fever caused by Brucella spp. The presence of Salmonella in some cheese samples and the high count of $S$. aureus (some having coagulase positive) in soft white cheese should be considered as a potential safety hazard. This is because of the absence of pasteurization in about $50 \%$ of the samples, and the poor hygiene conditions during production (as indicated also by the high SPC and LABC, and the relatively high numbers of Enterobacteriaceae).

Soft cheeses have higher moisture content when compared to hard cheese and have lower shelf life due to microbial spoilage. Most soft, unripen cheeses are microbiologically unstable due to metabolic activity of bacteria, yeast or mould contaminants [27]. It has been reported that the means of results of the microbiological analyses of the brined Turkish soft white cheese stored at $4^{\circ} \mathrm{C}$ were $6.1,3.1,3.9$,
$2.9 \log _{10}$ for total aerobic mesophoilic bacteria, Enterobacteriaceae, Staphylococci, and yeast and mold count, respectively [24]. El-Sayed et al. [20] found that Domiati and Tallaga cheese variety samples showed the higher aerobic colony bacterial counts (ACC) and the worst microbiological quality, as reached $\sim 10^{11}$ to $10^{12} \mathrm{CFU} / \mathrm{g}$ as a maximum count with an average $\sim 10^{7} \mathrm{CFU} / \mathrm{g}$. Meanwhile, Kariesh cheese variety, acid coagulation, showed higher molds and yeast count and the worst mycological quality as it reached $8 \times 10^{8} \mathrm{CFU} / \mathrm{g}$ with an average of $3 \times$ $10^{4} \mathrm{CFU} / \mathrm{g}$. Salmonella spp, has been only isolated from Domiati and Tallaga cheese varieties in $3 \%$ and $7 \%$ of the samples, respectively. The average total bacterial count for fresh white cheese samples collected from Tammoun and Tell villages in Palestine was $\log _{10} 7.7 \mathrm{CFU} / \mathrm{g}$. The present study demonstrated that all samples of fresh white cheese were negative for Salmonella. About $36 \%$ of samples of fresh soft white cheese had high levels of contamination by $S$. aureus. Recent studies showed similar microbiological characteristics in Sudanese white cheese (Gibna Bayda variety) [21], where at $0 \mathrm{~d}$ the total bacterial count (TBC), $S$. aureus and yeast and mold count were 7.5, 3.0, $2.7 \log _{10} \mathrm{CFU} / \mathrm{ml}$ of cheese. Total bacterial count (TBC), coliforms, E. coli, S. aureus and psychrotrophic bacterial counts significantly $(\mathrm{p}<0.05)$ decreased during storage, while yeasts and molds increased as storage time progressed. A Study by Hamid and El-Owni [23] on soft white cheese showed that the microflora was dominated by lactic acid bacteria (LAB) with evident mold and yeast growth. The previous study found that the average microbiological properties were $9.7 \log _{10} \mathrm{CFU} / \mathrm{ml}$ for total bacterial count; $3.3 \log _{10} \mathrm{MPN} / \mathrm{ml}$ coliforms; $0.70 \log _{10} \mathrm{MPN} / \mathrm{ml}$ E. coli; 1.7 $\log _{10}$ CFU/ml S. aureus; $5.1 \log _{10}$ CFU/ml lactic acid bacteria; $3.7 \log _{10}$ CFU/ml streptococci and $4.5 \log _{10} \mathrm{CFU} / \mathrm{ml}$ for yeast and mold counts. However, Salmonella spp. and Clostridium spp. were not detected in all the collected cheese samples. The average total bacterial count in Serbian soft white cheese [28] at $1 \mathrm{~d}$ brining was $7.3 \log _{10}$. Pesic-mikulec and Jovanovic [29] estimated the averages of $\log _{10}$ of aerobic mesophilic flora in fresh white cheese 9.3. Lactic acid bacteria were the major microbial group, reaching count similar to the total aerobic mesophilic flora at all sampling points of this study $\log _{10}$ of (9.2), whereas the counts of Enterobacteriaceae and mold and yeast counts were 4.2 and 5.6 , respectively. The mean values of coliforms bacteria, S. aureus, molds and yeasts of Iranian white brined cheese [22] were $4.1 \times 10^{2}, 4.5$ $\times 10^{3}, 4.5 \times 10^{3}$ and $9.2 \times 10^{4} \mathrm{CFU} / \mathrm{g}$, respectively. Also, the number of coliforms, S. aureus, and molds in 10.1, 10.1 and $34.2 \%$ of the samples were higher than the limits allowed by the national standard for Iranian industrial white ripened cheese. Furthermore, E. coli, faecal coliforms, and positive coagulase $S$. aureus were isolated from 58.4, 62.9, and $18 \%$ of the samples, respectively, but also two of thirty samples (7\%) of Salmonella were positive in $25 \mathrm{~g}$ of sample. Chemical parameters such as $\mathrm{pH}$ was 4.7 , titratable acidity 1.4 , dry matter $41.6 \%, \mathrm{NaCl} 4.3 \%$ and ash $5.9 \%$ were also determined.

According to the Jordanian standard (JS 246: 2006), salt ( $\mathrm{NaCl} \%$ ) should not exceed $10 \% \mathrm{wt} . / \mathrm{wt}$. in the final product, calculated as wet weight, whereas acidity (lactic acid\%) should not exceed $1.9 \%$. There is a report demonstrated that some pathogenic microorganisms, including L. monocytogens, and S. aureus in found soft cheese [30]. S. aureus, were isolated from different Egyptian varieties of white soft cheese in rates of $25.7 \%$, respectively [20]. Therefore, the presences of these pathogens in $26 \%$ of the total white soft cheese samples were not accepted according to the Egyptian standard (ES) 1008-2000. In a study of brined Turkish cheese, it was shown that Staphylococcus had low numbers (ranged from 1.3 to $1.7 \log _{10}$ CFU/g) of $S$. aureus, were Salmonella spp. and C. perfringens not present from the cheese samples [31]. A study by Al-As'ad [32] showed that the positive rate among Brucella samples in Syrian soft white cheese were $3.8 \%$ from a total number of 394 samples 
tested. The study added that the presence of Brucella in soft white cheese is proportional to the concentration of salt, since the presence of Brucella would be higher percentage in unsalted than salted cheese.

Based on the findings of this study, there is a need for developments urgently needed to improve the quality and ensure the safety of the product. Baledi or Jibnah Khadra mountain soft cheese produced in Lebanon did not preserve well and many cases of brucellosis infections have been associated with their consumption [27]. It is customary in Jordan in the previous to drink raw milk and eat fresh cheese; however, this habit has been found to be an important epidemiological factor in contracting brucellosis [33,34]. In this regard, the following is proposed: Use of clean milk from microbiological point of view (free of pathogens and has a low microbial load). Also, pasteurization of milk should be mandatory step in the production (as required by the Jordanian standard for soft cheese [35], avoid cross contamination, application of good manufacturing practice (GMP) during production, and maintenance of the cooling chain from milking till consumption of the cheese. Testing of soft white cheese for phosphatase should be a part of the governmental quality control testing of the product. To have an application of these conditions, calls for action from private and governmental interested parties is required.

\section{Conclusion}

From the results of this study, it could conclude that the lack of standardized method for production and keeping of soft white cheese in Jordan had resulted in the significant variations noticed in the different quality characteristics of the cheese samples. The high microbial content of the soft white cheese samples reflects the poor general hygiene conditions during production and storage of milk and cheese, lack of refrigeration and absence of steps such as heat treatment to eliminate microorganisms. It was noticed that the predominant microorganisms of soft white cheese are LABC, which have no negative effect on the safety of the products. Enterobacteriaceae counts in soft white cheese indicate direct or indirect fecal contamination of the milk or the product during processing, and thus the possibility of contamination with pathogenic bacteria, viruses, or protozoa of fecal origin.

Presence of Salmonella and contamination with S. aureus indicates indicate poor handling or sanitation and such foods certainly pose a threat to consumers. This urgently required new cleaning and safety procedures should be emphasized and checked by government in cheese factories. It is obvious that yeast growth in soft white cheese is not encouraged by the presence of LAB and the intrinsic conditions of the cheese, and this leads to the fact that the microbial flora of this cheese is bacterial rather than fungal. Keeping the traditional soft white cheese in a brine with $7 \%$ salt $(\mathrm{NaCl})$ concentration proved to be most suitable, since at this concentration the taste of the cheese was not negatively affected.

\section{References}

1. Haddadin JY (2005) Kinetic studies and sensorial analysis of lactic acid bacteria isolated from white cheese made from sheep raw milk. Pak J Nutri 4: 78-84.

2. Humeid MA, Tukan SK, Yamani MI (1990) In-bag steaming of white brined cheese as a method for preservation. Milchwissenchaft 45: 513-516.

3. Humeid MA, Tukan SK (1986) Towards improving the traditional method of producing boiled brined white cheese (Nabulsi Cheese). Dirasat 13: 19-29.

4. Yamani MI, Humeid MA, Tukan SK (1987) Comparing keeping ability of brined boiled white (Nabulsi) cheese packed in plastic pouches using cold and hot brines. Dirasat 14: 179-186.

5. Herzallah SM (1994) A study of the effect of different combinations of ph and salt concentrations of the brine on the storage ability and sensory quality of boiled white cheese (Nabulsi). University of Jordan, Amman, Jordan.

6. Abu-Alruz K, Mazahreh AS, Quasem JM, Hejazin RK, El-Qudah JM (2009) Effect of proteases on meltability and stretchability of nabulsi cheese. America J Agri Bio Sci 4: 173-178.

7. Tubesha $\mathrm{ZH}$ (2002) A study to produce fungal rennin-like enzyme and its use in the manufacturing of nabulsi cheese. University of Jordan, Amman, Jordan.

8. Abu-Alruz K (1999) A study of in-can heating preservation of nabulsi cheese with emphasis on halotolerant bacteria. University of Jordan, Amman, Jordan.

9. Saleh MI (1998) A study of the halophilic bacteria of nabulsi cheese, and their effect on the quality of the product. University of Jordan, Amman, Jordan.

10. Yamani MI, Al-Nabulsi AA, Haddadin MS, Robinson RK (1998) The isolation of salt tolerant bacteria from ovine and bovine milks for use in the production of nabulsi cheese. Int J Dairy Technol 51: 86-89.

11. Haddadin MY, Shahin RA (1995) Nabulsi: A Jordanian cheese. Dairy Ind Int 60: 33-35.

12. Abu-Ghoush MM (1992) Effect of the addition of yoghurt whey to cow's milk on curd formation and the effect of direct pasteurization on quality and safety of white brined cheese. University of Jordan, Amman, Jordan

13. Laird DT, Lenarz G, Scher FM, Graham TE, Reddy R (2004) Microbiological count methods: Standard methods for the examination of dairy products (Chapter 6). APHA, Washington DC, USA

14. Frank JF, Yousef AE (2004) Tests for groups of microorganisms: Standard methods for the examination of dairy products (Chapter 8). APHA, Washington DC, USA.

15. Henning DR, Flowers R, Reiser R, Ryser ET (2004) Pathogens in milk and milk products: Standard methods for the examination of dairy products (Chapter 5 ) APHA, Washington DC, USA

16. Hooi R, Barbano DM, Bradley RL, Budde D, Bulthaus M, et al. (2004) Chemical and physical methods: Standard methods for the examination of dairy products (Chapter 15). APHA, Washington DC, USA.

17. Case RA, Bradley RL, Williams RR (1985) Chemical and physiological methods: Standard methods for the examination of dairy products (Chapter 18). APHA, Washington DC, USA.

18. SAS (2012) Statistical analysis software: Version 9. SAS Institute Inc, Cary, NC, USA.

19. Delwiche LD, Slaughter SJ (2003) The little SAS book: A primer. SAS Institute Inc, Cary, NC, USA.

20. El-Sayed MA, Hosny I, El-Kholy WI, El-Dairouty RK, Mohamed HS (2011) Microbiological evaluation of Egyptian white soft cheeses style. J America Sci 7: 517-526.

21. El-Owni OA, Hamid IA (2008) Effect of storage period on weight loss, chemical composition, microbiological and sensory characteristics of sudanese white cheese (Gibna Bayda). Pak J Nutri 7: 75-80.

22. Mirazaei $H$, Khosroshahi AG, Karim G (2008) The microbiological and chemical quality of traditional lighvan cheese (White cheese in brine) produced in Tabriz, Iran. J Animal Vet Adv 7: 1594-1599.

23. Hamid IA, El-Owni OA (2007) Microbiological properties and sensory characteristics of white cheese (Gibna bayda) collected in Zalingei Area, West Darfur State. Res J Animal Vet Sci 2: 61-65.

24. Temelli S, Anar S, Sen C, Akyuva P (2006) Determination of microbiological contamination sources during Turkish white cheese production. Food Cont 17 856-861.

5. Sengul M (2006) Microbiological characterization of civil cheese, a traditional Turkish cheese: Microbiological quality, isolation, and identification of its indigenous Lactobacilli. World J Microbiol Biotechnol 22: 613-618.

26. Hayaloglua AA, Guvena M, Fox PF (2002) Microbiological, biochemical and technological properties of turkish white cheese 'Beyaz Peynir'. Int Dairy J 12 : 635-648.

27. Tannous RI (1991) Miscellaneous white brined cheeses: Feta and related cheeses. Ellis Horwood Ltd, England.

28. Stojiljković $J$ (2009) Influence of the pH of milk, cheese mass and brine on a complete number of bacteria during the production of white soft cheese. Biotechnol Animal Husb 25: 725-735. 
Citation: Haddad MA, Yamani MI (2017) Microbiological Quality of Soft White Cheese Produced Traditionally in Jordan. J Food Process Technol 8: 706. doi: $10.4172 / 2157-7110.1000706$

Page 6 of 6

29. Pesic-mikulec D, Jovanovic L (2005) Microbiological study of fresh white cheese (A Serbian craft variety). Appl Ecol Environ Res 4: 129-134.

30. Ryser ET (1998) Public health concern: Applied dairy microbiology. Marcel Dekker Inc, New York, USA.

31. Turantas F, Unluturk A, Goktan D (1989) Microbiological and compositional status of Turkish white cheese. Int J Food Microbiol 8: 19-24

32. Al-as'ad O (2000) Detecting Brucella in white cheese. Damascus University, Syria.
33. Abu Shaqra QM (2000) Epidemiological aspects of Brucellosis in Jordan Europe J Epidemol 16: 581-584.

34. El-Daher N, Nawas T, Al-Qaderi S (1990) The effect of the $\mathrm{pH}$ of various dairy products on the survival and growth of Brucella Melitensis. Trop Med Parasit 84: 523-528.

35. JISM (2006) JS 246: Jordanian standard of soft cheese. Jordanian Institute for Standards and Metrology, Jordan 